\title{
Upland Tenurial Program for Environment and Natural Resources Governance: The Northern Luzon Experience
}

\author{
Dr. Imelda Valdez- Iglesias ${ }^{1}$, Dr. Rogelio P. Pascua ${ }^{2}$ \\ Nueva Vizcaya State University, Bayombong, Nueva Vizcaya
}

\begin{abstract}
The need to properly manage watersheds is more pressing now than it has ever been. The increasing demand for water, timber, land, and other valuable watershed resources alongside the worsening negative impacts of local and global phenomena have brought the necessity for sustainable watershed management to a higher level. This study focused on the effectiveness of three upland tenurial programs in Northern Luzon like Community-Based Forest Management (CBFM), MUYUllg Resource Permit (1RP), and TREE for Legacy (TFL). The study used the descriptive comparative and predictive, quantitative, and qualitative methods of research with structured questionnaire and an interview. The study found that The CBFM and TFL programs were "very effective". The implementers of TFL and CBFM program have higher degree of competence compared to the muyung resource permit program. The program involvement and participation of the stakeholders from the TFL and CBFM programs were higher than the program involvement and participation of the MRP stakeholders. The TFL and CBFM programs were more effective compared to MRP program. There were five variables that are considered as best predictors of effectiveness of the tenurial programs. These were the "government/institutional support", "program planning and development", "capability development", "program monitoring" and 1/ communication methods and techniques".
\end{abstract}

Keywords: Muyung Resource Permit, TREE for Legacy, Community Based Forest Management Program, Tenurial Program

\section{Introduction}

Forests play a vital role in everyday life of every human on earth. The forests provide water for millions of people relying on natural springs; filter polluted air to make it breathable again; and also source of food, medicine, shelter and livelihood for countless benefits of people in the tropics. These and other countless benefits can be derived from this precious gift of nature (Culhi, 1998). Development in the uplands can never be achieved without the concerted efforts of the different sectors in our society. These sectors involve the program authorities on the government side, the NonGovernment Organizations (NGOs), the academe, the business and industry, and most importantly the communities; they work within their development programs (Pascua, 2007). Recognizing the communities as partners in development rather than as beneficiaries or takers of program services or as forest destroyers is an important principle in achieving success in promoting a sustainable upland or forest management (Cerilles, 20(0).

In order to sustain the development programs, three upland tenurial programs are being implemented by the Department of Environment and Natural Resources. These programs are: the Muyung Resource Permit (Memorandum Circular No. 02); the TREE for Legacy Program (DENR Administrative Order No. 30, series 1992); and Community-Based Forest Management Program (Executive Order 263) otherwise known as all people-oriented forestry programs.

These upland tenurial programs would encourage community support in national reforestation and would provide those community people opportunities to participate and have an assurance to get benefits from the forested areas. Nevertheless, project management and implementers play a vital role for the success of every project. They serve as the catalyst of development being the experts who have the knowledge, skills, and proper attitudes. However, the grave state of poverty in the rural areas has been a key factor in the social unrest in the countryside. In many developing countries, development activities have been concentrated primarily on the urban or more accessible areas where the greater number of people can be served with minimum effort and expense (Sudaypan, 20(9).

The need to properly manage watersheds is more pressing now than it has ever been. The increasing demand for water, timber, land, and other valuable watershed resources alongside the worsening negative impacts of the local and global phenomena such as the EI Nino, La Nina, and global warming have brought the necessity for sustainable watershed management to a higher level (Coli antes, 2005).

As the overall strategy to rehabilitate and develop the uplands, there is a need to continuously examine the program vis-a vis other DENR programs and current realities obtained in the forestry sector. It is a very important component for any CBFM plan for the sector.

Thus, this study assessed the extent of implementation of the upland tenurial programs in the forest areas in Northern Luzon. 


\section{International Journal of Science and Research (IJSR) \\ ISSN (Online): 2319-7064 \\ Index Copernicus Value (2013): 6.14 | Impact Factor (2015): 6.391}

\section{Framework}

\section{Conceptual Framework of the Study}

Senator Juan M. Flavier in sponsoring the Indigenous People's Rights Act (IPRA) of 1997 in the Senate stated: Land is the IPs worship area (religious), their institution for learning (educational), their area of governance (political), their livelihood and marketplace (economic), their medical center (health), their shelter (defense and security), their identity (personality and character), and their history (social). Osingat (2007) stated that depriving the indigenous peoples of their domain is just like depriving them of their right to live. Dulag as mentioned by Culhi (1998) strongly stressed that our race owns the land because only the race lives forever.

This study is guided with indicators that would conceive that upland tenurial programs for environment and natural resource governance are effective programs and strategies in attaining sustainable forest management. The management competencies in the implementation of the programs are due to the various acquisition of knowledge, and development of skills through training, dialogue, on the job training, discussion and other hone of development (Calimag, 2(04). The Department of Environment and Natural Resources (DENR) builds on the competence of their foresters and employees. The foresters and employees do not develop plans and seek capabilities, instead, build capabilities and then encourage the development of plans for implementation and improvements of the environment and natural resources governance programs (Estipona, 20(3).

Capabilities are often the agencies' most important resource. At the same time, the complexity and opaqueness of a firm's capabilities creates a management problem of its own. To capitalize on an organization's resources, managers need to be able to identify them, make decisions on exploiting and expanding. Without this knowledge, successful strategies would only be the lucky result of historical decisions or accidents. To understand how firms acquire and expand their capabilities, there is a need to tum to learning theory. The three stages in the learning process are knowledge acquisition, knowledge sharing, and knowledge utilization. Knowledge dissemination is highly formal in some agencies, but in other companies, it occurs informally through networking or casual interactions. Agencies also differ in the areas in which they invest in learning. The Department of
Environment and Natural Resources (DENR) usually develops through learning by doing, which demands no specific intervention from managers. At times, managers may need to accelerate the development of competencies. Organizational focus on improving and gaining specific competence may challenge existing power structures, or undermine naturally emerging competencies. Managers may misidentify the competencies which would be encouraged. Similar dilemmas arise with each of the key processes of competence management. The resources and capabilities include all the financial, physical, human, and organizational assets used by a firm to develop, manufacture, and deliver products or services (Pascua, 2007).

The managerial competence of implementers may be attributed on these competencies such as: 1) program planning and development, 2) communication methods and techniques, 3) program coordination, 4) program implementation, 5) program monitoring, 6) community relations and leadership, 7) program evaluation, and 8) community relations and leadership. The extent of government and institutional support may be determined through the following factors such as: 1) program advocacy and awareness, 2) budget/facilities/tools and equipment, 3) technical capability enhancement, and 4) managerial capability enhancement. The level of stakeholders' capability development may be considered in terms of: 1) environmental awareness and consciousness, 2) program involvement and participation, and 3) knowledge and skills acquisition development. The degree of effectiveness of the tenurial programs may be evaluated on the following criteria such as: 1) security of tenure, 2) promotion of social justice, 3) ensuring ecological integrity, and 4) financial stability.

Specifically, as reflected in Figure 1, the study further conceptualizes that the managerial competence of implementers/managers, government institutional support, and stakeholders' capability building are presumed to have significant differences when grouped according to the three upland tenurial programs.

Furthermore, the degree of managerial competence, the government and institutional support, and stakeholders' capability development are presumed to have significant difference on effectiveness of upland tenurial programs towards sustainable development through environment and natural resources stability, environmentally conscious and empowered community, and economically self-reliant community. 


\section{International Journal of Science and Research (IJSR) \\ ISSN (Online): 2319-7064}

Index Copernicus Value (2013): 6.14 | Impact Factor (2015): 6.391

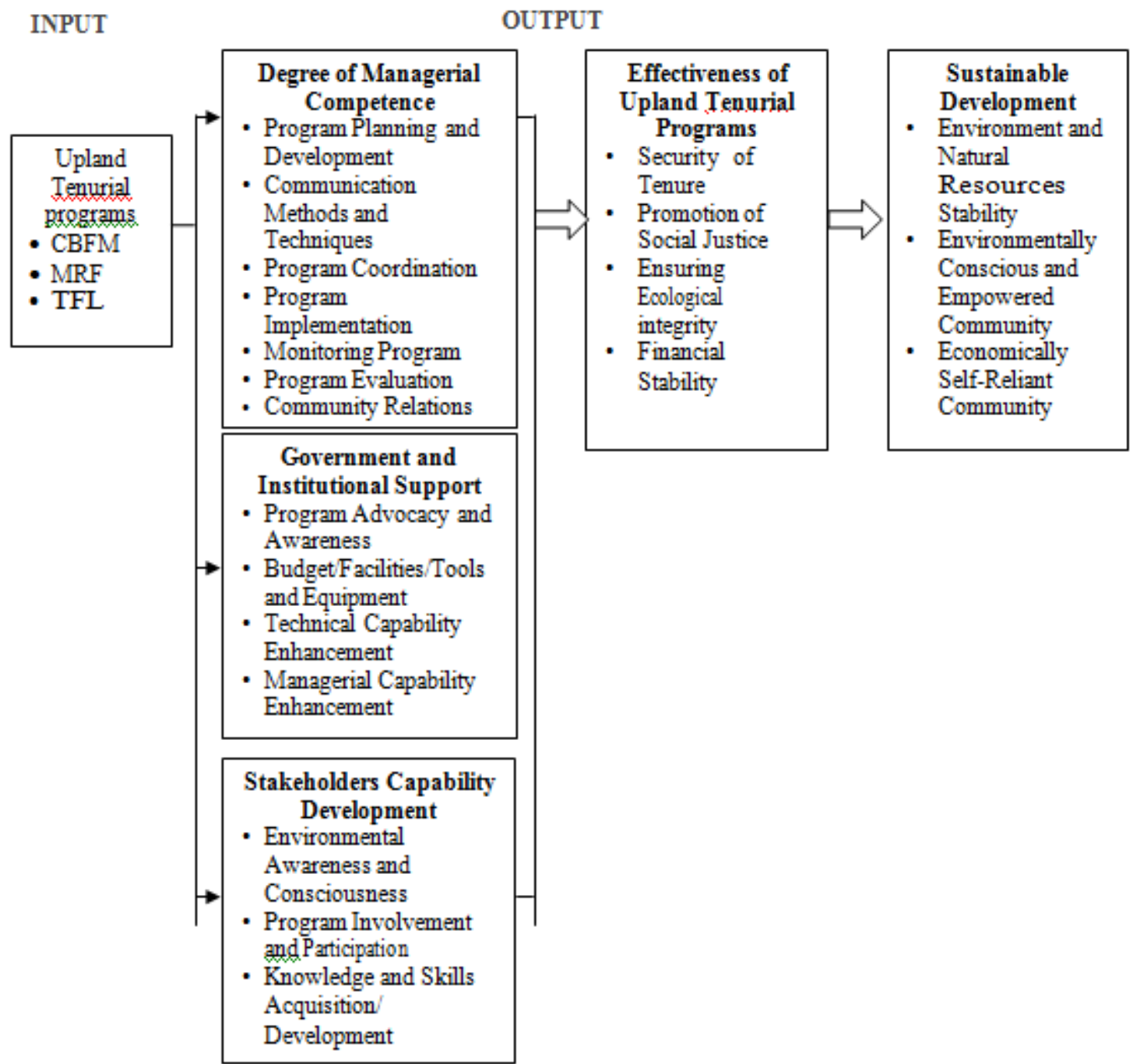

Figure 1: The conceptual paradigm of the study showing the relationship of the variables

\section{Objective of the Study}

The study sought to assess the extent of implementation of the upland tenurial programs in the forest areas in Northern Luzon.

\section{Materials and Methods}

\section{Research Design}

The research used the descriptive and comparative, predictive, quantitative and qualitative methods such as documentary analysis, focus group discussion and interview. The descriptive part described the demographic profile of the respondents; the degree of managerial competence of the implementers/managers in the implementation of the environment and natural resources governance program; the extent of government/institutional support in the implementation of the environment and natural resources governance program; the level of stakeholders' capacity development; and the degree of effectiveness of the upland tenurial programs. The qualitative methods of research were used to enrich the degree of effectiveness of the three upland tenurial programs.

\section{Research Instrument}

A five-part structured questionnaire was used in the study. Part I was used to obtain the profile of the program managers and implementers:

Part II, to determine the degree of managerial competence in the implementation of upland tenurial programs for ENR governance; Part III, to ascertain the extent of government and institutional support; Part IV, to assess the level of stakeholders' capability development; and Part V, to evaluate the degree of effectiveness of upland tenurial programs. A structured interview guide was used for the focus group discussion and interview with selected implementers/rnanagers and beneficiaries to validate the effectiveness of each upland tenurial program.

\section{Statistical Treatment of Data}

Frequency count, percentage, and arithmetic mean were used to describe the profile of the implementers/managers

Volume 5 Issue 5, May 2016 


\section{International Journal of Science and Research (IJSR) \\ ISSN (Online): 2319-7064 \\ Index Copernicus Value (2013): 6.14 | Impact Factor (2015): 6.391}

and beneficiaries. Mean was utilized to present the degree of managerial competence, extent of government and institutional support, extent of stakeholder's capability development and the degree of effectiveness of the different tenurial programs. In presenting the data for degree of managerial competence, government and institutional support, stakeholders' capability development and the effectiveness of upland tenurial programs for ENR governance, the following scales with their qualitative descriptions were used Analysis of Variance (ANOVA) or F-test was used to determine the differences on the extent of competence level of implementers/ managers, government and institutional support, stakeholders' capability development and effectiveness when grouped according to the upland tenurial program. Multivariate procedure, spedfically the multiple regression analysis was used to determine the best predictors on the effectiveness of the tenurial programs considering the managerial competence, stakeholders' capability development and government and institutional support.

\section{Results and Discussion}

\section{Effectiveness of the Upland Tenurial Programs}

\section{CBFM}

Summary of effectiveness of upland tenurial program (CBFM)

\begin{tabular}{|l|c|c|}
\hline \multicolumn{1}{|c|}{$\begin{array}{c}\text { Effectiveness of Upland Tenurial } \\
\text { Program (CBFM) }\end{array}$} & \multicolumn{2}{c}{ Im } \\
\cline { 2 - 3 } & Mean & S \\
\hline A. Security of tenure & 3.57 & 0.43 \\
\hline B. Promotion of Social Justice & 3.23 & 0.26 \\
\hline C. Ensuring Ecological Integrity & 4.25 & 0.44 \\
\hline D. Financial Stability & 3.30 & 0.25 \\
\hline Over-all & 3.59 & 0.27 \\
\hline
\end{tabular}

The result was supported by an interview with Bumidang. $\mathrm{He}$ stated that with exemplary performance of BCBAI in project implementation specifically comprehensive site development, forest protection and even in the advocacy of environmental and good governance, they were always the priority of DEN'R as project proponent to assure good result and as an incentive for always a job well done. This was supported by the statement of dela Cruz wherein Banila CBFM had received several awards such as Model and Sustainable Development Project (Upland Category) in the Province of Nueva Vizcaya and in Region 02 for three (3) consecutive years (CY 20002002) with a total cash award of Php 300,000.00. In 2006, they again bagged and garnered the 2006 Gender and Development (GAD) Search Award as the 2"'i Most GAD
The implementers and beneficiaries perceived that the CBFM program properly advocated security of tenure to the stakeholders as revealed by the overall mean scores of 3.57 for the implementers and 3.73 for beneficiaries, both were described" very effective". The perception of the implementers on the effectiveness of the project in the promotion of social justice was "effective". The mean scores recorded were 3.74 for implementers and 3.23 for beneficiaries.

The CBFM program was "very effective" in ensuring ecological integrity in the locality or community where the program was adopted. This is revealed by the overall mean scores of 4.25 from implementers-respondents and 4.06 from beneficiaryrespondents both falling in the same description level of "very effective". The mean scores for the financial stability of the MRP project were 3.26 and 3.24, both were indication that the project was effective as perceived by the implementers and beneficiaries.

Overall, the CBFM program was "very efficient" as perceived by the respondents. Both the two groups of respondents obtained overall mean scores of 3.59 and 3.83 equivalent to the description mark of "very effective". This further indicates that the program was effective in advocating security of tenure, promoting social justice, promoting ecological integrity and stability in financial aspect.

Table 2: Summary of effectiveness of upland tenurial program (MRP)

\begin{tabular}{|c|c|c|c|c|c|c|}
\hline \multirow{2}{*}{$\begin{array}{c}\text { Effectiveness of Upland Tenurial } \\
\text { Program (CBFM) }\end{array}$} & \multicolumn{3}{|c|}{ Implementers } & \multicolumn{3}{|c|}{ Beneficiaries } \\
\hline & Mean & SD & Extent & Mean & SD & Extent \\
\hline 1. $\quad$ Security of tenure & 3.15 & 0.43 & Effective & 3.18 & 0.43 & Effective \\
\hline Promotion of Social Justice & 3.17 & 0.26 & Effective & 3.21 & 0.29 & Effective \\
\hline Ensuring Ecological Integrity & 3.53 & 0.44 & Very Effective & 3.48 & 0.35 & Effective \\
\hline Financial Stability & 3.26 & 0.25 & Effective & 3.24 & 0.22 & Effective \\
\hline Over-all & 3.28 & 0.27 & Effective & 3.28 & 0.24 & Effective \\
\hline
\end{tabular}




\section{International Journal of Science and Research (IJSR) \\ ISSN (Online): 2319-7064 \\ Index Copernicus Value (2013): 6.14 | Impact Factor (2015): 6.391}

The MRP implementers perceived the project to be "very effective" in ensuring ecological integrity, and the beneficiaries thought that the program was just "effective". These different level of perceptions were based on the mean score of 3.53 described "very effective" of the implementers and the 3.48 described "effective" of the beneficiaries. The mean scores for the financial stability of the MRP project were 3.26 and 3.24, both were indication that the project was effective as perceived by the implementers and beneficiaries.

Overall, the MRP respondents equally obtained the mean score of 3.28 with a description of "effective". This further implies that the MRP program was a success in advocating security and tenure, promoting social justice, ensuring ecological and financial stability as perceived by the implementers and beneficiaries.

Based on an interview, Buccahan and Dulnuan mentioned that with all the issues, problems and challenges encountered in the implementation of the MRP, the program still considered very effective as upland tenurial program in the Province of Ifugao, $\sim \mathrm{fRP}$ holders were given privilege to avail seedlings from DENR nurseries making the muyung sustainable as a support system for the irrigation of the rice terraces, and as an effective measure for soil erosion. Based on the statistical record of PENRO Ifugao, a total 219 permits holders with a total land area more or less 433 hectares with a total recommended volume of more or less 6,800 cubic meters for harvests. The data is an evidence for the effectiveness of the MRP as upland tenurial program for environment and natural resource governance.

\section{TFL}

The over-all mean scores of 3.64 for the implementers and 3.98 for beneficiaries were the indications that the TFL program was very effective" in advocating security of tenure. The perception of the TFL implementers on the effectiveness of the project in promoting social justice obtained a mean score of 3.39 with a description of "effective", quite different from that of the perception of the beneficiaries having a mean of 3.94 with a description of "very effective". However, a combined mean score of 3.67 was obtained with a "very effective" qualitative description.

The two groups of respondents perceived the program to be "very effective" in ensuring ecological integrity. Indication of this statement was the over-all mean scores for the aspect of ensuring ecological integrity to be 4.08 and 4.24 - The perception of the implementers on financial stability which was" effective", and the perception of the beneficiaries were" very effective". The combined mean scores of 3.18 for the implementers and 4.06 for the beneficiaries was 3.62, belonged under the description mark of "very effective", hence the over-all perceptions of the group on the capability of the program in terms of financial aspect was livery efficient".

The over-all mean scores for the tenurial program was 3.57 for the implementers and 4.06 for the beneficiaries, both with a description mark of livery effective". It implies that the TFL program was perceived very efficient in advocating security of tenure, providing social justice, ensuring ecological integrity and in stabilizing financial capability of the group or members of the program. This finding was supported by an interview with Monsanto. He mentioned that the area is often times visited by different elementary pupils, high school and college school students, and was once visited by the Governor of Sarangani. One of the ABS-CBN personnel conducted documentation for the publication of the success of the Caliat TFL.

Table 3: Summary of effectiveness of upland tenurial program (TFL)

\begin{tabular}{|c|c|c|c|c|c|c|c|}
\hline \multirow{2}{*}{\multicolumn{2}{|c|}{ Effectiveness of Upland Tenurial Program (CBFM) }} & \multicolumn{3}{|c|}{ Implementers } & \multicolumn{3}{|c|}{ Beneficiaries } \\
\hline & & Mean & $\mathrm{SD}$ & Extent & $\mathrm{Me}$ & $\mathrm{S}$ & Extent \\
\hline 5. & Security of tenure & 3.64 & 0.51 & Very Effective & 3.9 & 0. & Very $\mathrm{E}$ \\
\hline 6. & Promotion of Social Justice & 3.39 & 0.38 & Effective & 3.9 & 0.2 & ctive \\
\hline 7. & Ensuring Ecological Integrity & 4.08 & 0.61 & Ver & 4.2 & 0. & \\
\hline 8. & Financial Stability & 3.18 & 0.61 & & 4.6 & 0. & \\
\hline & & & 0.40 & Effective & 4.0 & 0.2 & \\
\hline
\end{tabular}

Differences on Managerial Competence Level

\section{Program Planning and Development}

The implementers of the three tenurial programs had significant differences on the degree of competence in program planning and development as revealed by the F-value of 5.738 with corresponding significance value of OJ)04 The implementers of Tree for Legacy Program and Community Based Forest Management program had higher degree of competence compared to the muyung resource permit program as denoted by the mean scores of 3.694,. 3.638 and 3.459, on that order. This implies that the implementers of the Muyung Resource Permit program obtained a lower competence level in program planning and development when compared to the implementers from the two other tenurial programs. There were also some program planning and development indicators where the competence levels of the implementers were significantly varied.

The mean scores on the implementors' competence on the "Developing projects/research proposals and feasibility studies planning and implementation" showed an F-value of 4.887 and significance value of 0.008 , which means that there were mean score differences. Further testing, the scheffe post-hoc test revealed that the implementers to the TREE for Legacy were more competent in "developing projects research proposals and feasibility studies planning and implementation" 


\section{International Journal of Science and Research (IJSR) \\ ISSN (Online): 2319-7064 \\ Index Copernicus Value (2013): 6.14 | Impact Factor (2015): 6.391}

compared to the implementers of the Muyung Resource Permit program. This conclusion was based on the corresponding mean scores of 3.788 and 3.406 , respectively.

Table 4: Summary of the differences on managerial competence of implementers in the three upland tenurial

\begin{tabular}{|c|c|c|c|c|c|}
\hline $\begin{array}{l}\text { Managerial } \\
\text { Competence }\end{array}$ & Project & Mean & $S D$ & $F$ & Signature \\
\hline \multirow{3}{*}{$\begin{array}{l}\text { A. Program Planning } \\
\text { and Development }\end{array}$} & MRP & $3.459 \mathrm{~b}$ & 0.359 & 5.738 & 0.004 \\
\hline & CBFM & & & & \\
\hline & TFL & & & & \\
\hline \multirow{3}{*}{$\begin{array}{l}\text { B. Communication } \\
\text { Methods and } \\
\text { Techniques }\end{array}$} & MRP & & & & \\
\hline & $\overline{\mathrm{CBFM}}$ & & & & \\
\hline & TFL & & & & \\
\hline \multirow{3}{*}{$\begin{array}{l}\text { C. Program } \\
\text { coordination }\end{array}$} & MRP & 3.780 & 0.5 & 0.191 & 0.826 \\
\hline & \begin{tabular}{|l|} 
CBFM \\
\end{tabular} & 3.832 " & 0.677 & & \\
\hline & TFL & $3.785^{\prime \prime}$ & 0.4 .50 & & \\
\hline \multirow{3}{*}{$\begin{array}{l}\text { D. Program } \\
\text { Implementation }\end{array}$} & MRP & $3.820^{\bullet}$ & 0.568 & 0.675 & 0.510 \\
\hline & CBFM & $3.733^{\bullet}$ & 0.621 & & N N \\
\hline & TFL & $3.704^{\bullet}$ & 0.575 & & \\
\hline \multirow{3}{*}{$\begin{array}{l}\text { E. Program } \\
\text { Monitoring }\end{array}$} & MRP & $3.710^{\bullet}$ & 0.528 & 0.364 & 0.695 \\
\hline & CBFM & $3.638 \mathrm{a}$ & 0.597 & & \\
\hline & TFL & 3.692 • & 0.565 & 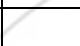 & \\
\hline \multirow{3}{*}{$\begin{array}{l}\text { F. Program } \\
\text { Evaluation }\end{array}$} & MRP & $3.614^{\prime}$ & 0.519 & 0.830 & 0.437 \\
\hline & CBFM & $3.729^{\prime}$ & 0.575 & & \\
\hline & TFL & $3.669 \mathrm{a}$ & 0.629 & & W \\
\hline \multirow{3}{*}{$\begin{array}{l}\text { G. Community } \\
\text { Relations and } \\
\text { Leadership }\end{array}$} & MRP & $3.397 "$ & 0.468 & 7.016 & 0.001 \\
\hline & CBPM & $3.602 \bullet$ & 0.460 & & ( \\
\hline & TFL & $3.715 \mathrm{a}$ & 0.537 & & \\
\hline \multirow{3}{*}{ Overall } & MRP & $3.623 \bullet$ & 0.348 & 0.714 & 0.491 \\
\hline & CBFM & $3.694^{\prime}$ & 0.469 & 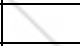 & \\
\hline & TFL & $3.705 \bullet$ & OA77 & & \\
\hline
\end{tabular}

Common superscripts $a, b$ or $c$ show groups that were not significantly different from each other as established by the used of scheffe post hoc test. Uncommon superscripts $a, b$ or $c$ show groups that were significantly different from each other.

The implementers from the TREE for Legacy Program and Community Based Forest Management Program were more competent in "utilizing research findings for ENR program activities planning and implementation" compared to the implementers from the Muyung Resource Permit Program. This conclusion was based on the P-value of 6.4, significance value of 0.002 and to the corresponding mean scores of $3.69,3.55$ and 3.22 respectively.

The mean score of 3.769 for the implementers from TREE for Legacy Program was found to be significantly higher than the mean score of 3.319 for the implementers from the Muyung Resource Permit Program. This statement was based on the sheffe post hoc test and F-value of 5.369 and significance value of 0.005 . This further implies that the implementers from the TREE for Legacy Program were more competent in conceptualizing and developing of training programs appropriate for identified community needs" compared to the implementers from the Muyung Resource Permit.

\section{Program Management}

The implementers from TREE for Legacy Program and Community Based Forest management program exhibit higher competency level in "putting the plan into action" compared to the implementers from the Muyung Resource Permit Program. This conclusion was based on the F-value of 8.255 and significance value of $<0.0001$ and supported by the sheffe post hoc test based on the mean scores of 3.750, 3.556 and 3.246, respectively. This implies that there was sufficient fund to supplement implementation of program plans and activities of CBFM and TFL. The major target of CBFM and TFL implementers was the implementation of plans and activities while the MRP program is not a priority of the MRP implementers due to their multiple designations. It could also be attributed due to insufficient fund to finance the MRP plans and activities. Pambid mentioned during an interview that tviRP is not a priority program of the DENR/government, as an evidence, the DENR is not allocating any fund for the program and activities, it only served as additional function of DENR Ifugao.

\section{Communication Methods and Techniques}

The communication methods and techniques of the implementers from the three (3) tenurial projects is of equal competence level. The corresponding mean scores of 3.577 for MRP, 3.687 for CBfM and 3.673 for TFL were not significantly different from each other, based on the F-value of 0.796 and significance value of 0.452 .

The implementers' competency along the indicators of communication methods and techniques from the three programs were not different from each other. This suggests that the implementers have effective communication methods and techniques in disseminating important information to their beneficiaries.

\section{Program Coordination}

The implementers from the three tenurial programs had the same degree of competency with regard to program coordination. This statement was manifested from the mean scores 3.780 of MRP, 3.832 of CBFM and 3.785 of TFL with the corresponding F-value of 0.191 with significance value of 0.826. This implies that the implementers of the tenurial programs exhibit similar practices in coordinating from the community to the agency.

The three groups of implementers had similar degree of competency along the indicators of program coordination. Perhaps they have similar practices in working/coordinating with other DENR offices and employees for a better interpretation and implementation of ENR programs policy guidelines", "working/coordinating with other agencies for enhanced program implementation and complementation", "coordinating with other development program implementers and institution", "working with community leaders to perpetuate ENR program plan of activities" and "coordinating

Volume 5 Issue 5, May 2016 


\section{International Journal of Science and Research (IJSR) \\ ISSN (Online): 2319-7064 \\ Index Copernicus Value (2013): 6.14 | Impact Factor (2015): 6.391}

with community leaders for standard and timely implementation of ENR program activities" .

\section{Program Implementation}

Although, seemingly, the MRP mean score of 3.820 obtained the highest mean score followed by the CBFM with 3.733 and the TIL with 3.704, the F-value of 0.675 together with the significance value of 0.510 suggests that these mean scores were statistically the same. This inferred that the degree of competence of the implementers from the three tenurial programs were of the same degree. Furthermore, this implies that there is no deviation of program implementation from the other groups.

The F-values and significance values along the program implementation indicators denoted no significant differences on mean scores. It could be further inferred that the competence level of the implementers, likewise the practices of the irnplementers in implementing the program were not different from the other tenurial programs. All implementers were equally competent in "applying basic control methods and techniques in ENR programs", "providing technical inputs in the implementation of ENR programs", "organizing community and collaborating with the barangay officials and stakeholders for standard and timely implementation of ENR activities", "developing promotional and model sites", and "developing implementation mechanism of income generating projects".

\section{Program Monitoring}

The E-value of 0.364 and Significance value of 0.695 established the conclusion that the competency level of the three groups of implementers in program monitoring was not different from each other. Since all the implementers belonged to the same agency, was expected all of them were required to submit ocular reports, on site reports and terminal reports, due to these it is made possible that the implementers from other projects falls on the same competency level.

This suggests that the MRP, CBFM and TIL implementers equally conducts "monitoring progress of activities in ENR programs", "identify ENR program, problem areas and activities that needs to be improved", "recognizing properly implemented activities and accomplishments", " applying measures to identify and correct impediments' in the accomplishment of goals and objectives of ENR", "preparing monitoring chart and report" and "holding regular quarterly meeting to monitor program performance".

\section{Program Evaluation}

The over-all mean scores 3.614, 3.729 and 3.669 of program evaluation of the tvfRP, CBFM and TFL, in that order, were not significantly different from each other as evaluated by the f-value of 0.830 with significant value of 0.437 . This conclusion implies that the implementers from the three different tenurial programs had the same degree of competence as to program evaluation. It shows that the implementers from the three groups exhibits similar level of competence along the indicators of program evaluation such as /I designing and applying ENR program evaluation methods", "conducting cost-benefit/cost-effectiveness analysis of Et-.I'R programs", "constructing and utilizing data gathering instruments", "constructing community situational analysis as a basis for re-planning ENR programs" and "Providing recommendations to improve ENR program implementation".

Furthermore, it could be inferred that all the implementers employed similar strategies in evaluating the program. This conclusion was based on the mean scores, F-values and the significance values.

\section{Community Relations and Leadership}

The over-all mean scores 3.715 of the TFL and 3.602 of the CBFM were significantly higher than the over-all mean score, 3.397 of the MRP with regard to the implementers' community relation and leadership. This conclusion was based on the scheffe post hoc-test and to the prior analysis on the F-value of 7.016 and 0.001 of the significance value. This implies that irnplementers from the TFL and CBFM were more competent in community relation and leaderships compared to the implementers from theMRP.

There were indicators with mean scores of the three tenurial programs exhibit significant differences. The indicators were as follows:

The implementers from the TFL were with higher competence level in "organizing and motivating community people/stakeholders to participate in ENR program activities", "identifying community leaders, priming groups and guiding them effectively", "establishing rapport for the mobilization of community people/stakeholders", "providing leadership on the formulation, implementation, supervision and evaluation of ENR programs", "seeking assistance from other institution", and "revitalizing and sustaining networks" when compared to the implementers from the MRP Program,

It was also concluded that the implementers from TIL and CSFM were more competent in II conducting regular capability building of stakeholders until they could start on their own" compared to the implementers from the MRP program. This conclusion was based on the mean scores, Fvalue and the significance value.

In general, the over-all mean scores for the implementers/managers level of competence did not show significant differences when compared with each other.

Differences on the Government and Institutional Support It was found out that the program and advocacy awareness extended to the TFL and CBFM were much higher than the MRP. This conclusion was based on the mean scores of 3.660, 3.562 and 2.957 which further concluded by the F-value of 33.384 with significance value of $<0.0001$. The TFL and

Volume 5 Issue 5, May 2016 


\section{International Journal of Science and Research (IJSR) \\ ISSN (Online): 2319-7064 \\ Index Copernicus Value (2013): 6.14 | Impact Factor (2015): 6.391}

CBFM implementers conducted more" consultation, conference, training, workshop, conference, and meeting", "presents project concept", strengthens "community involvement on project planning", gives more "access to organizational linkages and network" and entered to an /I agreed-on shared responsibilities" compared to the implementers of the MRP.

\section{Budget/Facilities/Tools and Equipment}

As to budget/facilities/tools and equipment in support to the program, the TFL and CSFM programs were given much support coming from the government and institution compared to the MRP program. Likewise, the TFL program got ample support from the government and institution compared to the CSFM as perceived by the respondents. These conclusions were based on the F-value of 42.808 with significance value of $<0.0001$ and the scheffe post-hoc test.

Table 5: Summary of differences of the government and institutional support in the three upland tenurial programs

\begin{tabular}{|c|c|c|c|c|c|}
\hline Government and Institutional Support & Project & Mean & SD & $\mathrm{F}$ & Signature \\
\hline \multirow[t]{3}{*}{ A. $\quad$ Program Advocacy and Awareness } & MRP & $2.957 "$ & 0.674 & 33.384 & $<0.0001$ \\
\hline & CBFM & $3.562 \mathrm{a}$ & 0.495 & & \\
\hline & TFL & $3.669 \mathrm{a}$ & 0.439 & & \\
\hline \multirow[t]{3}{*}{ Budget/Facilities/ fools and equipment } & MRP & $2.643^{\prime}$ & 0.655 & 42.806 & $<0.0001$ \\
\hline & CBFM & $3.299 \mathrm{~b}$ & 0.611 & & \\
\hline & TFL & $3.642 \cdot$ & 0.565 & & \\
\hline \multirow[t]{3}{*}{ Technical capabilit } & MRP & $12.670^{\prime}$ & 0.459 & 51.415 & $<0.0001$ \\
\hline & CBFM & $3.170 \mathrm{~b}$ & 0.618 & & \\
\hline & TFL & $3.688 \bullet$ & 0.519 & 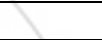 & \\
\hline \multirow[t]{3}{*}{ D. Managerial Capability Enhancement } & MRP & $2.409^{\prime}$ & 0.468 & 82.022 & $<0.0001$ \\
\hline & CBFM & $2.956 \mathrm{~b}$ & 0.541 & & \\
\hline & TFL & $3.581^{\prime}$ & 0.452 & & \\
\hline \multirow[t]{3}{*}{ Overall } & MRP & $2.670^{\mathrm{b}}$ & 0.409 & 82.058 & $<0.0001$ \\
\hline & CBFM & 3.246 & 0.477 & & \\
\hline & TFL & $3.645^{\prime}$ & 0.328 & & \\
\hline
\end{tabular}

Common superscripts $\mathrm{a}, \mathrm{b}$ or $\mathrm{c}$ shows groups that were not significantly different from each other as established by the use of scheffe post hoc test. Uncommon superscripts a, b or c show groups that were significantly different from each other.

The TFL program acquired so many benefits from the government and institution in support of the program, followed by the CBFM program and the least was the MRP program as perceived by the respondents for the supports like "Fund availability and allocation", "timely release of program fund", "provision of supplies/equipment for program activities", "availability and proper scheduling of transportation and mobility facilities" and "provision of financial assistance during natural disaster and calamities" .

\section{Technical Capability Enhancement}

As to the technical capability enhancement, the perception of the respondents from the TFL project was significantly higher than the perception of the respondents from the CBFM and MRP respondents as indicated by the mean scores of 3.669, 3.562 and 2.957 , in that order.

Likewise, the perception of the respondents from the CBFM project was significantly higher than the MRP program.

The following were the technical capability enhancement introduced to the three tenurial programs; the "conduct of onsite technical trainings", "establishment of field school (demo sites)", "conduct of cross farm visit (educational tour)", "provision of extension materials/ packaged technology" and 1/ adoption /promotion of proven best practices" .

\section{Managerial Capability Enhancement}

There were significant differences established on the managerial capability enhancement among the three tenurial programs. The perception of the respondents from the TFL program was higher than the perceptions of the respondents from CBFM and MRP programs. Likewise, the perception of the CBFM respondents was higher than the perception of the respondents from the TFL program. These conclusions were based on the mean scores of 3.581, 2.956 and 2.409. This further implied that there were more managerial capability trainings conducted for the TFL projects, followed by those in CBFM and the least was those in the MRP program.

The respondents from the TFL program were aware that there were more conduded formations and organizational trainings, assisted the members in formulation and implementation of by-laws, sponsor trainings to have a more sustainable resources, strengthen organizational linkages, and teaches effective documentation and safe record-keeping compared to the other two tenurial programs. It was also identified that the respondents from the MRP projects had the little awareness on the above stated management capability enhancement. 


\section{International Journal of Science and Research (IJSR) \\ ISSN (Online): 2319-7064 \\ Index Copernicus Value (2013): 6.14 | Impact Factor (2015): 6.391}

\section{Differences on Stakeholders' Capability Development}

\section{Environmental Awareness and Consciousness}

Based on the over-all mean scores of the three tenurial programs; 3.362 of the tvf RP, 3.699 of the CBFM and 3.762 of the TFL and F-value of 7.449 with significance value of 0.001 on the stakeholders' capability development particularly the environmental awareness and consciousness showed that there exist mean differences. The mean scores of the TFL and CBFM were significantly higher than the mean score of the MRP. The result further implied that the environmental awareness and consciousness of the TFL and CBFM stakeholders were higher than the environmental awareness and consciousness of the MRP stakeholders.

Specifically, the TFL and CBFM stakeholders were more aware and more conscious along the application of basic environmental principles", adoption of ecological solid waste management", application of soil erosion control techniques", "identification and selection of suitable species for planting" and "timing of plantation establishment" compared to MRP stakeholders. These conclusions were based on the F-values of $5.707,3.110,7.764, .5 .563$ and 7.445 with corresponding significance values of all less than 0.05 level of Significance.

Table 6: Summary of differences of stakeholders' capability development in the three upland tenurial programs

\begin{tabular}{|c|c|c|c|c|c|}
\hline $\begin{array}{c}\text { Stakeholders' Capability } \\
\text { Development }\end{array}$ & Project & Mean & SD & $\mathrm{F}$ & Signature \\
\hline \multirow{3}{*}{$\begin{array}{l}\text { A. Environmental } \\
\text { Awareness and } \\
\text { Consciousness }\end{array}$} & MRP & 3.362 & 0.741 & 7.449 & 0.0001 \\
\hline & CBFM & 3.699 & 0.670 & & \\
\hline & TFL & 3.762 & 0.421 & & \\
\hline \multirow{3}{*}{$\begin{array}{l}\text { B. Program } \\
\text { Involvement and } \\
\text { Participation }\end{array}$} & MRP & $3.559 \bullet$ & 0.861 & 3.705 & 0.0026 \\
\hline & CBFM & $3.830^{\bullet}$ & 10.724 & & 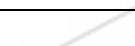 \\
\hline & TFL & $3.873 \mathrm{a}$ & 0.507 & & $Z$ \\
\hline \multirow{3}{*}{$\begin{array}{lr}\text { C. } & \text { Knowledge } \\
\text { and Skills } & \text { Acquisition }\end{array}$} & MRP & $3.501 \mathrm{bc}$ & 0.597 & 6.472 & 0.0002 \\
\hline & CBFM & $3.869^{\prime}$ & 0.726 & D & \\
\hline & TFL & $3.781^{\prime \prime \prime}$ & 0.605 & 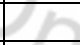 & 14 \\
\hline \multirow[t]{3}{*}{ Overall } & MRP & $3.474 \mathrm{c}$ & 0.663 & 6.812 & 0.0001 \\
\hline & CBFM & $3.799 \bullet$ & 0.645 & 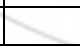 & \\
\hline & TFL & 3.805 & 0.442 & & \\
\hline
\end{tabular}

Common superscripts $a, b$ or $c$ snows groups that were not significantly different from each other as established by the used of scheffe post hoc test. Uncommon superscripts $a, b$ or $c$ show groups that were significantly different from each other.

\section{Program Involvement and Participation}

Based on the program involvement and participation of the stakeholders from the three different tenurial programs, the Fvalue of 3.705 with significance value of 0.026 suggested that there exists mean differences. Using scheffe, it was identified that the mean score of the respondents from TFL (3.873) was significantly different from the mean score of the respondents from the MRP (3.559). This further suggested that the program involvement and participation of the stakeholders from the

TFL program was higher than the program involvement and participation of the MRP stakeholders.

There were no significant differences established along the indicators "program planning", "program implementation", "program monitoring and evaluation" and "program review and assessment" as indicated by the F-values of 2.338, 2.360, 1.310 and 2.823 with significance values of all higher than 0.05 level of significance (Appendix N). This further implied that the three tenurial programs had the same activities on planning, implementation. monitoring, evaluation, review and assessment.

On the other hand, the F-value of 9.457 and significance value of $<0.0001$ implied that there exist mean differences on the stakeholders' program management. Based on the corresponding mean scores of 3.827 of the TFL, 3.747 of the CBFM and 3.304 of the $\sim \mathrm{fRP}$, the mean scores of TFL and CBFM were Significantly higher than the mean score of the MRP. This further suggests that the TFL and CBFM programs exhibited higher or more program involvement and participation to its stakeholders compared to the MRP stakeholders.

\section{Knowledge and Skills Acquisition/Development}

The F-value of 6.472 with significance value of $p=0.002$ or $<0$ suggested that there exists mean differences on the overall mean score of stakeholders' acquisition of knowledge and development of skill. It was identified that CBFM mean score was higher than the MRP mean score. This implies that the CBFM stakeholders possessed better knowledge and skill compared to the MRP stakeholders along the given indicators.

The TFL and CBFM stakeholders acquired/develop skills much better than the MRP stakeholders, skills in "plantation design, layout and planning", "nursery management and propagation techniques" and "plantation layout and establishment". This conclusion was based on the F-values of $7.91,5.185$ and 7.343 with significance value of all less than 0.05 level of significance and later with the use of sdieffe post hoc test. The F-value of 3.049 with significance value of $\mathrm{p}=$ 0.049 suggested that there was significant difference on mean scores along the "adoption of soil conservation measures", which was later identified to be CBFM mean score was higher than the MRP mean score. This further implies that the CBFM stakeholders acquired knowledge/skills in adopting the soil conservation measures compared to MRP stakeholders. On the other hand, the F-value of 2.422 with significance value of 0.091 suggested that there was no significant difference on the mean scores of the stakeholders along the indicator "Plantation protection and maintenance". This further implies that all the stakeholders equally gained knowledge/skills in plantation protection and maintenance.

Differences on Effectiveness of Upland Tenurial Programs

Volume 5 Issue 5, May 2016 


\section{International Journal of Science and Research (IJSR) \\ ISSN (Online): 2319-7064 \\ Index Copernicus Value (2013): 6.14 | Impact Factor (2015): 6.391}

\section{Security of Tenure}

It was identified that the mean score of the TFL and CBFM were significantly higher than the mean score of the MRP. It was also established that the TFL and CBFM programs were best in "controlling the exploitation of the forest in the coverage area", "protecting the landholdings from land speculators", "protecting the natural resources of holdings from exploiters", regulating the entry of migrant settlers in the area covered by the project", "ensuring land security of tenure of beneficiaries", "access to the forest land resources under long term tenurial agreements", and "defining landholdings of each member" compared to the tvfRP program.

Table 7: Summary of differences on effectiveness of the three upland tenurial programs

\begin{tabular}{|c|c|c|c|c|c|}
\hline $\begin{array}{c}\text { Stakeholders' } \\
\text { Capability } \\
\text { Development }\end{array}$ & Project & Mean & SD & $\mathrm{F}$ & Signature \\
\hline \multirow{3}{*}{$\begin{array}{l}\text { A. Security of } \\
\text { Tenure }\end{array}$} & MRP & $3.275 \mathrm{~b}$ & 0.765 & 18.454 & $<0.0001$ \\
\hline & CBFM & $3.838^{\prime}$ & 0.6 & & 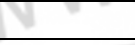 \\
\hline & TFL & $3.942^{\prime}$ & 0.539 & 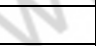 & \\
\hline \multirow{3}{*}{$\begin{array}{l}\text { Promotion of } \\
\text { Social justice }\end{array}$} & MRP & $3.072 \mathrm{~b}$ & 0.551 & 27.354 & $<0.0001$ \\
\hline & CBFM & $3.667^{\prime}$ & 0.623 & & \\
\hline & TFL & $3.769 \bullet$ & 0.581 & 1 & \\
\hline \multirow{3}{*}{$\begin{array}{c}\text { Ensuring Ecological } \\
\text { Integrity }\end{array}$} & MRP & $3.609 \mathrm{~b}$ & 0.623 & 23.102 & $<0.0001$ \\
\hline & CBFM & $4.182 \bullet$ & 0.578 & & $\square$ \\
\hline & TFL & $4.212 \bullet$ & 0.572 & & 7 \\
\hline \multirow[t]{3}{*}{ Financial Stability } & MRP & $3.217 \mathrm{~b}$ & 0.415 & 20.105 & $\infty$ \\
\hline & CBFM & 3.727 & 0.620 & & \\
\hline & TFL & $3.846 \bullet$ & 0.777 & & \\
\hline \multirow[t]{3}{*}{ Overall } & MRP & 3.277 & 0.245 & 69.996 & \\
\hline & CBFM & $3.814^{\bullet}$ & 0.370 & & \\
\hline & TFL & $3.918 \bullet$ & 0.373 & & \\
\hline
\end{tabular}

Common superscripts $a, b$ or c shows groups that were not significantly different from each other as established by the used of scbeffe post hoc test. Uncommon superscripts $\mathrm{a}, \mathrm{b}$ or $\mathrm{c}$ shaw groups that were significantly different from each other.

\section{Promotion of Social Justice}

The mean scores 3.769 of the TFL and 3.667 of the CBFM were significantly higher than the mean score of the tvtRP. Specifically, the TFL and CBFM programs can best "guarantee the free practice of indigenous peoples of customary laws within the project area", "incorporate the needs and aspirations of local communities whose livelihood depends on the forest lands in the program implementation", "protect the customs, traditions and beliefs of indigenous peoples in the formulation of laws and policies", "guarantee the free practice of customary laws in resolving conflicts/issues within the project area", "employ laborintensive methods in accessing forest land resources, redemption of lands which are unjustly taken by encroachers, and satisfaction on the size of landholdings allotted by the project.", and "maintain the customs and traditions and beliefs of indigenous peoples as they go about their life in their indigenous ways of wisely utilizing the forests as sources of almost all their needs" compared to the MRP program.

\section{Ensuring Ecological Integrity}

The TFL and CBFM programs were more effective in ensuring ecological integrity compared to the MRP program. It was also concluded that TFL and CBFM program were best in "enforcing laws that preserve, maintain and restore ecological balance of the domain", "employing environmentfriendly, ecologically-sustainable, and labor-intensive methods in accessing forest land resources", "incorporating labor intensive practices on the wise utilization of the forest resources and in the process of creating livelihood opportunities for the beneficiaries and nearby communities", and "promoting and advocating tree planting and reforestation" compared to MRP program.

\section{Financial Stability}

The TFL and CBFM programs were proven more effective compared to the $\sim \mathrm{fRP}$ project in terms of financial stability (Appendix 0). The TFL and CBFM programs were consistently best in "seeking supplementary funding from local and foreign supporting agencies and organizations" , "providing financial and professional incentives system for deserving communities", "providing financial and professional incentives system for deserving communities", "sourcing out local and international grants and donations for the establishment of the project" and "effecting the creation of favorable financing mechanisms for access by communities and organizations" compared to MRP program.

\section{Over-all Effectiveness}

The mean scores for TFL/and CBFM programs were significantly higher than the mean score of the MRP which further conduded that the TFL and CBFM programs were more effective compared to MRP program.

The Best Predictors of Effectiveness of the Upland Tenurial Programs

Under the managerial competence of the implementers, the effectiveness was related to the degree of competence of implementers in program planning and development, and community relations and leadership. Under the government and institutional support, the effectiveness was related to all indicators of institutional support; such as "program advocacy and awareness", "budget/facilities/tools and equipment", "technical capability enhancement" and "managerial capability enhancement". Likewise the over-all government and institutional support was related to effectiveness.

The over-all capability development was related to effectiveness. The indicators "Environmental awareness and consciousness", "program Involvement and participation" and "knowledge and skills acquisition! development" were also related to effectiveness.

Volume 5 Issue 5, May 2016 


\section{International Journal of Science and Research (IJSR) \\ ISSN (Online): 2319-7064 \\ Index Copernicus Value (2013): 6.14 | Impact Factor (2015): 6.391}

All the variables that were found linearly associated to effectiveness were considered in multiple regression analysis. It was found out that there were five variables or factors that show great contributions to effectiveness namely; "government and institutional support", "program planning and development", "capability development", "program monitoring" and "communication methods and techniques" .

Table 8 (a): Predictors of effectiveness showing relationships to managerial competence, government and institutional support, and stakeholders' capability development

\begin{tabular}{|l|l|l|}
\hline \multirow{2}{*}{ Predictors of effectiveness OF Upland tenurial Program } & Effectiveness & Significance \\
\cline { 2 - 3 } & R value & 0.104 \\
\hline A. Managerial Competence & 0.085 & $<0.0001$ \\
\hline 1. Program Planning and Development & 0.263 & 0.325 \\
\hline 2. Communication Methods and Techniques & 0.031 & 0.426 \\
\hline 3. Program coordination & $-0.0 i s$ & 0.464 \\
\hline 4. Program Implementation &..$\{$ J.OO6 & 0.492 \\
\hline 5. Program Monitoring & 0.001 & 0.051 \\
\hline 6. Program Evaluation & 0.111 & 0.010 \\
\hline 7. Community Relation and Leadership & 0.157 & $<0.0001$ \\
\hline B. Government and Institutional Support & 0.383 & $<0.0001$ \\
\hline 1. Program Advocacy and Awareness & 0.287 & $<0.0001$ \\
\hline 2. Budget/Facilities/Tools and Equipment & 0.307 & $<0.0001$ \\
\hline 3. Technical capability enhancement & 0.333 & $<0.0001$ \\
\hline 4. Managerial capability enhancement & 0.359 & $<0.0001$ \\
\hline C. Stakeholders' Capability Development & 0.264 & $<0.0001$ \\
\hline 1. Environmental awareness and consciousness & 0.236 & $<0.0001$ \\
\hline 2. Program Involvement and participation & 0.233 & $<0.0001$ \\
\hline 3. Knowledge and skills acquisition/development & 0.248 & \\
\hline
\end{tabular}

Table 8b: Best predictors of effectiveness of the upland tenurial programs

\begin{tabular}{|l|l|l|l|l|l|}
\hline \multirow{2}{*}{ factors/variables } & Unstandardized Coefficients & Unstandardized Coefficients & T & Significance \\
\cline { 2 - 6 } & $\mathrm{B}$ & $\mathrm{SE}$ & $\mathrm{B}$ & & \\
\hline Constant & 2.266 & 0.251 & & 9.038 & $<1), 0001$. \\
\hline & & & & & \\
\hline 1. Government /Institutional support & 0.238 & 0.048 & 0.310 & 4.955 & $<0.0001$ \\
\hline 2. Program Planning and Development & 0.266 & 0.073 & 0.262 & 3.673 & $<1) .0001$ \\
\hline 3. Program Monitoring & -0.114 & 0.063 &..$(\mathrm{~J} .151$ & -1.823 & 0.070 \\
\hline 4. Capability development & 0.173 & 0.051 & 0.251 & 3.420 & 0.001 \\
\hline 5. Communication Methods and Techniques & -0.144 & 0.064 & -0193 & -2.267 & 0.024 \\
\hline R square value $=\mathbf{0 . 2 4 8}$ & \multicolumn{7}{|l|}{} \\
\hline
\end{tabular}

However, the combined predictability R2 value of 0.248 means that the association of the variables stated above is accounted for only $24.80 " .0$ or the total effectiveness of the tenurial programs could be explained $24 \mathrm{JSOO} / \mathrm{c}$, attributed to these five variables. The remaining percentages could be accounted to other factors not included in the study.

The variable that most contributory factor to effectiveness was the implementers' competence in "program planning and development", this obtained the highest B-value of 0.266 . This further implies that the higher the degree of competence of the implementer in program planning and development the higher the assurance of program effectiveness,

The second most contributory factor of program effectiveness was "the government/institutional support" the B-value of 0.238 was the basis for this statement. This implies that the higher the support coming from the government or institution, the more the program becomes effective. The third most contributory factor to program effectiveness was the "capability development" with Fvalue of 0.173 . The more the stakeholders' capability development offered to the group the more the program become stable and effective.

The fourth and fifth contributory factors were the "program monitoring" and "communication methods and techniques" with the least B-value both were equally -0.114 . This implies that the less the monitoring conducted the more effective the program to happen, and the less communication method and technique being employed and adopted the more the program becomes effective.

\section{Conclusions}

The CBFM and TFL programs were "very effective". The implementers of TFL and CBFM program have higher degree of competence compared to the Muyung Resource Perm it program. The program involvement and participation of the stakeholders from the TFL and CBFM programs were higher than the program involvement and participation of the MRP stakeholders. The TFL and CBFM programs were more

Volume 5 Issue 5, May 2016 www.ijsr.net 


\section{International Journal of Science and Research (IJSR) \\ ISSN (Online): 2319-7064 \\ Index Copernicus Value (2013): 6.14 | Impact Factor (2015): 6.391}

effective compared to MRP program. There were five variables that are considered as best predictors of effectiveness of the tenurial programs. These were the "government/institutional support", "program planning and development", "capability development", "program monitoring" and "communication methods and techniques".

\section{Recommendations}

1) The MRP implementers are advised to attend some leadership training that will improve or enhance their competence in community relation to have an effective program implementation.

2) The government through its lead agency should strengthen its support extended to the MRP project in terms of program advocacy and awareness campaign, allot a budget or funding for the program, improve the facilities and provide more sophisticated tools and equipment

3) The lead agency should conduct more awareness campaign on environmental awareness and consciousness, giving importance to adoption of basic environmental principles, ecological solid waste management, soil erosion control, different plant variety for culture and its timing of plantation.

4) The stakeholders of the MRP program especially the implementers and the concerned agency should try to consider re-designing the program to make it more effective.

5) The implementers through the agency concerned should adopt the best practices from the TFL and CBFM programs. The implementers should make some inventory of the best practices of the TFL or CBFM as their benchmark for them to consider in revitalizing the MRP program.

6) The implementers should make some initiative to remedy the problem. Perhaps, ask support from the other NGOs or make some linkages to other foundations that can give financial, technical or any support.

7) The lead agency should try to strengthen their support to the program especially in planning and development, and in improving capability of the program in developing ceofriendly individuals.

8) A research or study that will consider more variables not included is encouraged for exploration to explain the remaining 76 contributory to effectiveness.

\section{References}

[1] Cerilles, A. H. 2000. Community Based Forest Management Project, Policies and Guidelines Issuances, Manual, DENR, Visayas Avenue, Diliman, Quezon City.

[2] Collantes, 1. S. 2005. The Forest Protection Program of the DENR: Community Participation, Strategies and Future Challenges. Unpublished MS Thesis, School of Government and Management, University of Southeastern Philippines, Obrero Campus, Davao, City. Philippines.

[3] Culhi, L. M 1998 Sustainability of Ifugao Rice Terraces: An Evaluation. Unpublished Ph. D. Dissertation, Institute of Graduate Studies, Central Luzon State University, Science City of Munoz, Nueva Ecija Philippines.

[4] Estipona, E. E. 2003 Competence of DENR Supervisors in the Cordillera Administrative Region: An Assessment. Unpublished Thesis, Graduate School, Benguet State University, La Trinidad, Benguet. Philippines

[5] Osingat, L P. 2007 Effectiveness of the Bugkalot Certificate of Ancestral Domain Title as Tenurial Instrument of Nueva Vizcaya, Unpublished M.S. Thesis, Graduate School, Nueva Vizcaya State University, Bayombong, Nueva Vizcaya. Philippines.

[6] Pascua, R. P. 2007 Correlates of Job Performance of Community-Based Forest

[7] Management Implementers (CBFMP) in Ifugao. Unpublished M.S. Thesis, Graduate School, Nueva Vizcaya State University, Bayornbong, Nueva Vizcaya. Philippines.

[8] Sudaypan, C. T. 2009 Efficiency and Effectiveness of Community-Based Microhydro System for Electrification of Remote and Off-grid Communities in the Cordillera Unpublished PhD. Dissertation, Benguet State University, La Trinidad, Benguet, Philippines. 